\title{
Salivary Gland Large Cell Carcinoma
}

National Cancer Institute

\section{Source}

National Cancer Institute. Salivary Gland Large Cell Carcinoma. NCI Thesaurus. Code C35735.

A rare, highly aggressive carcinoma that arises from the salivary gland, predominantly the parotid gland. It is characterized by the presence of large pleomorphic malignant cells with abundant cytoplasm. Patients usually present with a rapidly growing mass. 